\title{
Innovative use of animal models to advance scientific research
}

\author{
D. K. Meyerholz ${ }^{1}$ - A. P. Beck ${ }^{2}$ - B. Singh ${ }^{3}$
}

Published online: 19 April 2020

(C) Springer-Verlag GmbH Germany, part of Springer Nature 2020

Animal models are a foundational tool and resource for scientists studying basic biological processes, disease pathogenesis, novel therapies/techniques, and toxicologic research (Brayton et al. 2019; Swindle et al. 2012; Wagar et al. 2018). While mice and rats have been the mainstay of research in the twentieth century, newer types of animal models have been developed based on emerging technologies. For instance, somatic cell nuclear transfer was used to develop Dolly the sheep and expanded the ability to create new transgenic large animal models (Rogers et al. 2008; Tan et al. 2016). Larger animal models can provide advantages compared to small animals for imaging, pathology, and surgical approaches to name a few. More recently, genome editing techniques have become popular because of their technical ease and low costs. These techniques have been used to rapidly develop new types and variations of animal models (Kalds et al. 2019; Krishnamurthy et al. 2019; Moon et al. 2019). In contrast, some models are developed and refined for study of a natural susceptibility to disease (Enkirch and von Messling 2015; McGill et al. 2019). As one might expect, the types and scopes of animal models continue to grow and become more refined.

In this special issue of Cell \& Tissue Research, we highlight several newer animal models and their uses in research. Beck and Meyerholz reviews some of the challenges in the use of

D. K. Meyerholz

david-meyerholz@uiowa.edu

\author{
A. P. Beck \\ amanda.beck@einstein.yu.edu \\ B. Singh \\ Baljit.singh1@ucalgary.ca
}

1 Department of Pathology, University of Iowa Carver College of Medicine, Iowa City, IA, USA

2 Department of Pathology, Albert Einstein College of Medicine, Bronx, NY, USA

3 Faculty of Veterinary Medicine, University of Calgary, Calgary, Canada animal models and clarifies their roles and limitations in the broader context of research (Beck and Meyerholz 2020). Webster et al. discussed the emerging roles for genetically engineered mice in drug development to complement current techniques as well as to address specific hypotheses (Webster et al. 2020). Animal models for neurological research have been refined and advanced in recent years and some of these are highlighted by Zeiss (Zeiss 2020). Large animals such as pigs have become increasingly studied for their immune response, and Pabst reviews these investigational opportunities (Pabst 2020). Renner et al. review how pig models can provide robust models for the study of metabolic syndrome and diabetes mellitus (Renner et al. 2020), while Zuidema and Sutovsky review how some have harnessed the genetics of pigs to better understand mitochondrial inheritance (Zuidema and Sutovsky 2020). Similarly, Zigo et al. review approaches to study porcine sperm and related fertility as a model for humans (Zigo et al. 2020), while Ibtisham reviews the use of spermatogonia stem cells in animal models (Ibtisham et al. 2020). Furthermore, a group of papers in this issue focuses on animal models to study lung pathophysiology. Grune et al. show how animal models can be used to validate noninvasive diagnostic techniques like ultrasound for an important clinical diagnosis of pulmonary edema (Grune et al. 2020). Bullone and Lavoie review the use of horses as a useful model to study the spontaneous occurrence and lung remodeling of asthma in humans (Bullone and Lavoie 2020). Sitthicharoenchai et al. review the use of a newborn lamb model to study RSV infection in infants (Sitthicharoenchai et al. 2020). Finally, Vrolyk and Singh review the biology of pulmonary intravascular macrophages (PIMs) in animal models of pancreatitis to raise the question whether PIMs are similarly recruited in humans, too (Vrolyk and Singh 2020).

While traditional rodent models have a rich history in biomedical research, new approaches and strategies to study animal models can significantly broaden, strengthen, and accelerate the impact of scientific research. The use of these models not only advances research in human diseases but also improves the health of companion and food production animals. 


\section{References}

Beck AP, Meyerholz DK (2020) Evolving challenges to model human diseases for translational research. Cell Tissue Res. https://doi.org/ 10.1007/s00441-019-03134-3

Brayton CF, Boyd KL, Everitt JL, Meyerholz DK, Treuting PM, Bolon B (2019) An introduction to pathology in biomedical research: a mission-critical specialty for reproducibility and rigor in translational research. ILAR J 59:1-3

Bullone M, Lavoie J (2020) The equine asthma model of airway remodeling: from a veterinary to a human perspective. Cell Tissue Res. https://doi.org/10.1007/s00441-019-03117-4

Enkirch T, von Messling V (2015) Ferret models of viral pathogenesis. Virology 479-480:259-270

Grune J, Beyhoff N, Hegemann N, Lauryn JH, Kuebler WM (2020) From bedside to bench: lung ultrasound for the assessment of pulmonary edema in animal models. Cell Tissue Res. https://doi.org/10.1007/ s00441-020-03172-2

Ibtisham F, Awang-Junaidi AH, Honaramooz A (2020) The study and manipulation of spermatogonial stem cells using animal models. Cell Tissue Res. https://doi.org/10.1007/s00441-020-03212-x

Kalds P, Zhou S, Cai B, Liu J, Wang Y, Petersen B, Sonstegard T, Wang $X$, Chen Y (2019) Sheep and goat genome engineering: from random transgenesis to the CRISPR era. Front Genet 10:750

Krishnamurthy S, Wohlford-Lenane C, Kandimalla S, Sartre G, Meyerholz DK, Theberge V, Hallee S, Duperre AM, Del'Guidice T, Lepetit-Stoffaes JP, Barbeau X, Guay D, McCray PB Jr (2019) Engineered amphiphilic peptides enable delivery of proteins and CRISPR-associated nucleases to airway epithelia. Nat Commun 10:4906

McGill JL, Kelly SM, Guerra-Maupome M, Winkley E, Henningson J, Narasimhan B, Sacco RE (2019) Vitamin A deficiency impairs the immune response to intranasal vaccination and RSV infection in neonatal calves. Sci Rep 9:15157

Moon SB, Kim DY, Ko JH, Kim YS (2019) Recent advances in the CRISPR genome editing tool set. Exp Mol Med 51:130

Pabst R (2020) The pig as a model for immunology research. Cell Tissue Res. https://doi.org/10.1007/s00441-020-03206-9

Renner S, Blutke A, Clauss S, Deeg CA, Kemter E, Merkus D, Wanke R, Wolf E (2020) Porcine models for studying complications and organ crosstalk in diabetes mellitus. Cell Tissue Res. https://doi.org/10. 1007/s00441-019-03158-9

Rogers CS, Stoltz DA, Meyerholz DK, Ostedgaard LS, Rokhlina T, Taft PJ, Rogan MP, Pezzulo AA, Karp PH, Itani OA, Kabel AC, Wohlford-Lenane CL, Davis GJ, Hanfland RA, Smith TL, Samuel M, Wax D, Murphy CN, Rieke A, Whitworth K, Uc A, Starner TD, Brogden KA, Shilyansky J, McCray PB Jr, Zabner J, Prather RS, Welsh MJ (2008) Disruption of the CFTR gene produces a model of cystic fibrosis in newborn pigs. Science 321:1837-1841

Sitthicharoenchai P, Alnajjar S, Ackermann MR (2020) A model of respiratory syncytial virus (RSV) infection of infants in newborn lambs. Cell Tissue Res. https://doi.org/10.1007/s00441-020-03213-w

Swindle MM, Makin A, Herron AJ, Clubb FJ Jr, Frazier KS (2012) Swine as models in biomedical research and toxicology testing. Vet Pathol 49:344-356

Tan W, Proudfoot C, Lillico SG, Whitelaw CB (2016) Gene targeting, genome editing: from Dolly to editors. Transgenic Res 25:273-287

Vrolyk V, Singh B (2020) Animal models to study the role of pulmonary intravascular macrophages in spontaneous and induced acute pancreatitis. Cell Tissue Res. https://doi.org/10.1007/s00441-02003211-y

Wagar LE, DiFazio RM, Davis MM (2018) Advanced model systems and tools for basic and translational human immunology. Genome Med 10:73

Webster JD, Santagostino SF, Foreman O (2020) Applications and considerations for the use of genetically engineered mouse models in drug development. Cell Tissue Res. https://doi.org/10.1007/s00441$019-03101-y$

Zeiss CJ (2020) Utility of spontaneous animal models of Alzheimer's disease in preclinical efficacy studies. Cell Tissue Res. https://doi. org/10.1007/s00441-020-03198-6

Zigo M, Maňásková-Postlerová $\mathrm{P}$, Zuidema $\mathrm{D}$, Kerns $\mathrm{K}$, Jonáková V, Tůmová L, Bubeníčková F, Sutovsky P (2020) Porcine model for the study of sperm capacitation, fertilization and male fertility. Cell Tissue Res. https://doi.org/10.1007/s00441-020-03181-1

Zuidema D, Sutovsky P $(2020,2019)$ The domestic pig as a model for the study of mitochondrial inheritance. Cell Tissue Res. https://doi.org/ 10.1007/s00441-019-03100-z

Publisher's note Springer Nature remains neutral with regard to jurisdictional claims in published maps and institutional affiliations. 